\title{
Chemoselective Polymerization of Epoxides from Carboxylic Acids: Direct Access to Esterified Polyethers and Biodegradable Polyurethanes
}

\author{
Ye Chen, $\uparrow$ Shan Liu, $\uparrow$ Junpeng Zhao $\dagger^{*}$, David Pahovnik,§ Ema Žagar,§ and Guangzhao Zhang $†$ \\ $\uparrow$ Faculty of Materials Science and Engineering, South China University of Technology, Guangzhou \\ 510640, China
}

$\$$ Key Laboratory of Luminescence from Molecular Aggregates of Guangdong Province, South China University of Technology, Guangzhou 510640, China

$\S$ Department of Polymer Chemistry and Technology, National Institute of Chemistry, Hajdrihova 19, 1000 Ljubljana, Slovenia

\section{Table of Contents}

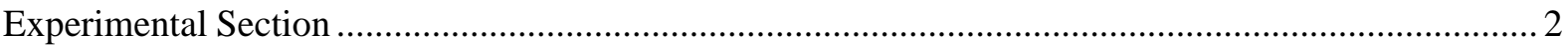

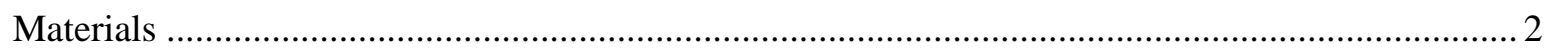

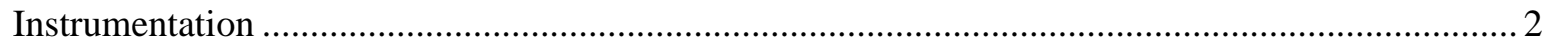

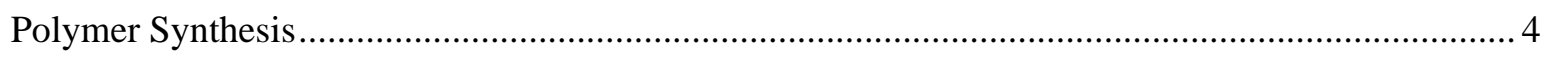

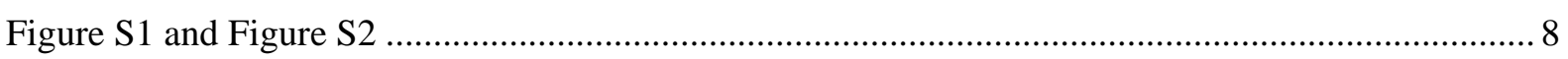

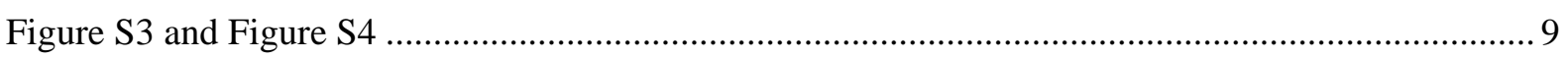

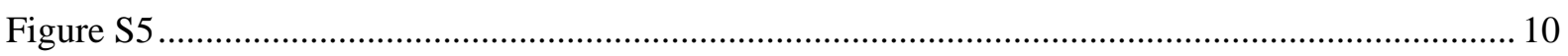

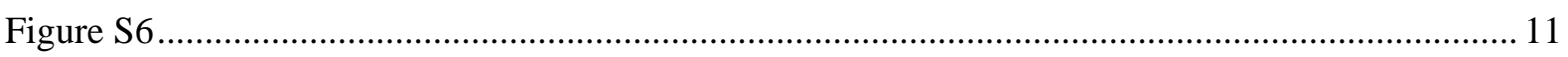

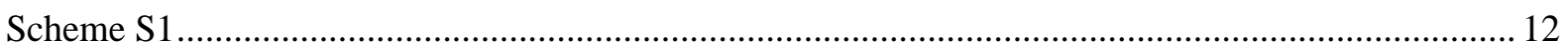

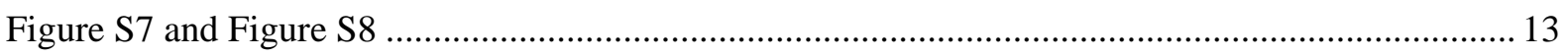

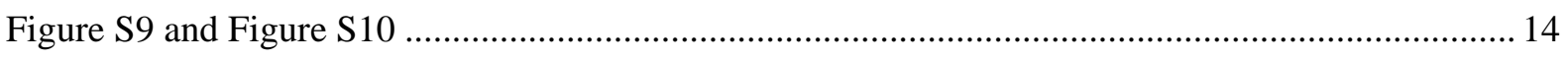

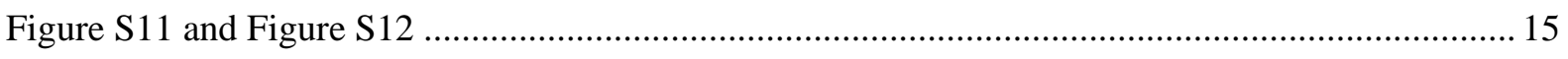

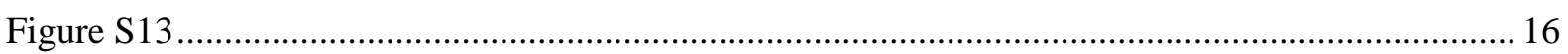

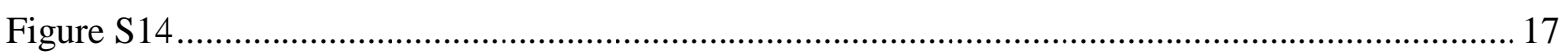

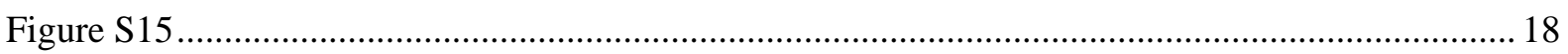

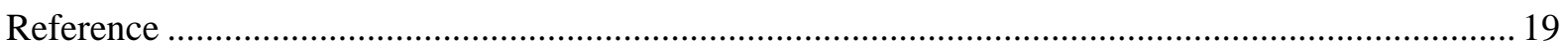




\section{Experimental Section}

\section{Materials}

Solvents, potassium hydroxide $(\mathrm{KOH}, \mathrm{AR})$, and hydrochloric acid $(\mathrm{HCl}, \mathrm{AR})$ were purchased from Guangzhou Chemical Reagent. Tetrahydrofuran (THF, AR) was dried successively over molecular sieve (4 $\AA$ ) and calcium hydride $\left(\mathrm{CaH}_{2}\right)$ before distilled. Stearic acid (SA, 98\%), benzoic acid (BA, 99\%), methacrylic acid (MA, 99\%), glutaric acid (GA, 99\%), triethylborane (Et 3 B, 1.0 M in THF), and hexamethylene diisocyanate (HDI, 99\%) were purchased from TCI (Shanghai). Phosphazene bases (PBs), including $t$-BuP2 $2.0 \mathrm{M}$ in THF) and $t$ - $\mathrm{BuP}_{1}(97 \%)$, ethylene oxide (EO, 99.5\%), propylene oxide (PO, 99\%), 1,2-butylene oxide (BO, 99\%), and allyl glycidyl ether (AG, 99\%) were purchased from Aldrich. SA, BA, MA and GA are dried on the vacuum line prior to use. EO was condensed in a Schlenk flask docked on the vacuum line and dried by stirring with sodium hydride $(\mathrm{NaH})$ in an ice-water bath for $4 \mathrm{~h}$, then cryo-condensed into a graduated cylindrical flask before finally cryocondensed into the reaction flask (EO is volatile with a boiling point of ca. $11{ }^{\circ} \mathrm{C}$ and toxic by inhalation, we recommend great caution in the process of drying and transferring). PO and BO were stirred with $\mathrm{NaH}$ at room temperature (RT; 23 26 ${ }^{\circ} \mathrm{C}$ ) before distilled. AG was stirred with $\mathrm{CaH}_{2}$ before vacuum-distilled. Et3 $\mathrm{B}$, HDI, $t-\mathrm{BuP}_{2}$, and $t$ - $\mathrm{BuP}_{1}$ were stored in an inert atmosphere and used as received.

\section{Instrumentation}

NMR spectra were recorded at $25{ }^{\circ} \mathrm{C}$ on a Bruker AV400 NMR spectrometer using deuterated chloroform $\left(\mathrm{CDCl}_{3}\right)$ or THF- $d_{8}$ as the solvent and tetramethylsilane as the internal standard. ${ }^{1} \mathrm{H}$ NMR spectra were used to calculate number-average molar mass $\left(M_{\mathrm{n}, \mathrm{NMR}}\right)$ of the 
(co)polyethers by comparing the integrals of signals from ester groups and polymer main bodies.

Size exclusion chromatography (SEC) for poly(ethylene oxide) (PEO) and EO-based copolyether was conducted in $N, N$-dimethylformamide (DMF) with $\mathrm{LiBr}(0.05 \mathrm{M})$ at $50{ }^{\circ} \mathrm{C}$ and a flow rate of $1.0 \mathrm{~mL} \mathrm{~min}{ }^{-1}$ using three successively connected Styragel columns (HR2, HR4, HR6). A series of narrowly dispersed poly(ethylene oxide) standards were used for calibration to obtain number-average molar mass $\left(M_{\mathrm{n}, \mathrm{SEC}}\right)$ and molar mass distribution $\left(\bigoplus_{\mathrm{M}}\right)$ of the synthesized PEOs. For poly(propylene oxide) (PPO), other substituted polyethers, and polyurethane (PU), SEC was conducted in THF at $35{ }^{\circ} \mathrm{C}$ using two identical PLgel MIXED$\mathrm{C}$ columns at the same flow rate. Calibration was done with a series of narrowly dispersed polystyrene (PS) standards to obtain apparent number-average molar mass $\left(M_{\mathrm{n}, \mathrm{SEC}}\right)$ and $\bigoplus_{\mathrm{M}}$ of the polymers.

Matrix assisted laser desorption/ionization time of flight mass spectrometry (MALDI-TOF MS) measurements were performed on a Bruker Autoflex III Smartbeam MALDI-TOF mass spectrometer (Bruker, Germany). The polymer sample and cationization agent $\mathrm{CF}_{3} \mathrm{COONa}$ were dissolved in THF (10 $\left.\mathrm{mg} \mathrm{mL}^{-1}\right)$. The matrix (2,5-dihdroxybenzoic acid) was also dissolved in THF $\left(20 \mathrm{mg} \mathrm{mL}^{-1}\right)$. Solutions of matrix, polymer, and cationization agent were mixed in a volume ratio of $20 / 5 / 1$. The mixed solution was spotted $(0.4 \mu \mathrm{L})$ on the MALDI sample plate and air-dried. Calibration was done externally with poly(methyl methacrylate) standards using the nearest neighbor positions.

Enzymatic degradation of the PPO-PU were monitored by quartz crystal microbalance with dissipation (QCM-D), which together with AT-cut quartz crystal with a fundamental resonance frequency of $5 \mathrm{MHz}$ was from Q-sense $\mathrm{AB}$. Briefly, the mass gain/loss of a thin layer on a quartz crystal is manifested by the decrease/increase in the resonance frequency of the crystal, whereas the dissipation factor is related to the viscoelastic properties of the 
additional layer. ${ }^{1}$ In the present study, phosphate buffer saline (PBS) was used as the reference. The lipase Pseudomonas (lipase PS) solution $\left(1.0 \mathrm{mg} \mathrm{mL}^{-1}\right)$ was delivered to the surface at a flow rate of $150 \mu \mathrm{L} \mathrm{min}{ }^{-1}$. All the experiments were performed at $25^{\circ} \mathrm{C}$, and the data presented were from the third overtone. The film was prepared by spin-coating of the PU solution ( 3 drops, $5.0 \mathrm{mg} \mathrm{mL}^{-1}$ in THF) on gold sensor followed by heating at $60{ }^{\circ} \mathrm{C}$ for $12 \mathrm{~h}$ and cooling at $25^{\circ} \mathrm{C}$ for $2 \mathrm{~h}$ before use.

\section{Polymer Synthesis}

Stearic Acid-Initiated ROP of PO Catalyzed by $t-B u P_{2}$ and $E t_{3} B$. A typical procedure is given as follows (SA-PO in Table 1). Stearic acid $(0.10 \mathrm{~g}, 0.35 \mathrm{mmol})$ was loaded in a reaction flask and dried by azeotropic distillation of THF on the vacuum line. The flask was then transferred in a glovebox where PO $(2.0 \mathrm{~mL}, 28.5 \mathrm{mmol}), t-\mathrm{BuP}_{2}$ solution $(2.0 \mathrm{M}, 9.0 \mu \mathrm{L}$, $0.018 \mathrm{mmol}), \mathrm{Et}_{3} \mathrm{~B}$ solution $(1.0 \mathrm{M}, 54.0 \mu \mathrm{L}, 0.054 \mathrm{mmol})$ were loaded. The mixture was stirred at RT. Aliquots $(c a .50 \mu \mathrm{L})$ were withdrawn at different time intervals and diluted with $0.6 \mathrm{~mL}$ of $\mathrm{CDCl}_{3}$ for ${ }^{1} \mathrm{H} \mathrm{NMR}$ analysis. The $\mathrm{CDCl}_{3}$ solution was further diluted with $\mathrm{THF}$ for SEC measurement. After $7 \mathrm{~h}$, the reaction mixture was quenched with acetic acid, diluted with THF and then poured in water to precipitate the polymer. The viscous liquid product was collected by centrifugation and dried in vacuum at $60{ }^{\circ} \mathrm{C}$ until a constant weight is reached. Conv. $(\mathrm{PO})=95 \%, M_{\mathrm{n}, \mathrm{th}}=4.8 \mathrm{~kg} \mathrm{~mol}^{-1} \cdot M_{\mathrm{n}, \mathrm{SEC}}(\mathrm{THF}, \mathrm{PS}$ standards $)=6.2 \mathrm{~kg} \mathrm{~mol}^{-1}$, $\bigoplus_{\mathrm{M}}=1.05 .{ }^{1} \mathrm{H} \mathrm{NMR}\left(400 \mathrm{MHz}, \mathrm{CDCl}_{3}\right): \delta / \mathrm{ppm}=4.09-4.01\left(-\mathrm{COOCH}_{2} \mathrm{CH}\left(\mathrm{CH}_{3}\right) \mathrm{O}^{-}\right), 3.97-$ $3.89\left(-\mathrm{OCH}_{2} \mathrm{CH}\left(\mathrm{CH}_{3}\right) \mathrm{OH}\right), 3.75-3.46\left(-\mathrm{OCH}_{2} \mathrm{CH}\left(\mathrm{CH}_{3}\right) \mathrm{O}^{-}\right)$, 3.46-3.25 $\left(-\mathrm{OCH}_{2} \mathrm{CH}\left(\mathrm{CH}_{3}\right) \mathrm{O}^{-}\right)$,

2.35-2.28 (- $\left.\mathrm{CH}_{2} \mathrm{CH}_{2} \mathrm{COO}-\right), \quad 1.65-1.55 \quad\left(-\mathrm{CH}_{2} \mathrm{CH}_{2} \mathrm{COO}^{-}\right), \quad 1.35-1.22$ $\left(\mathrm{CH}_{3}\left(\mathrm{CH}_{2}\right)_{14} \mathrm{CH}_{2} \mathrm{CH}_{2} \mathrm{COO}-\right.$ and $\left.-\mathrm{OCH}_{2} \mathrm{CH}\left(\mathrm{CH}_{3}\right) \mathrm{OH}\right), \quad 1.18-1.09 \quad\left(-\mathrm{OCH}_{2} \mathrm{CH}\left(\mathrm{CH}_{3}\right) \mathrm{O}^{-}\right)$, 0.90-0.86 $\left(\mathrm{CH}_{3}\left(\mathrm{CH}_{2}\right){ }_{14} \mathrm{CH}_{2} \mathrm{CH}_{2} \mathrm{COO}-\right) . M_{\mathrm{n}, \mathrm{NMR}}=5.1 \mathrm{~kg} \mathrm{~mol}^{-1}$. 
Stearic Acid-Initiated ROP of EO Catalyzed by $t-B u P_{1}$ and $E t_{3} B$. A typical procedure is given as follows (SA-EO in Table 1). A reaction flask was dried with a heat gun on a vacuum line and transferred in a glovebox, where THF $(2.0 \mathrm{~mL}), \mathrm{SA}(0.43 \mathrm{~g}, 1.5 \mathrm{mmol}), t-\mathrm{BuP}_{1}(17.5 \mu \mathrm{L}$, $0.075 \mathrm{mmol})$, and Et $3 \mathrm{~B}$ solution $(1.0 \mathrm{M}, 0.23 \mathrm{~mL}, 0.23 \mathrm{mmol})$ were successively loaded. The reaction flask was then docked back on the vacuum line, and purified EO $(6.0 \mathrm{~mL}, 120.0$ mmol) was cryo-condensed in at $0{ }^{\circ} \mathrm{C}\left([\mathrm{EO}]_{0}=14.0 \mathrm{M}\right)$. Then the reaction mixture was slowly warmed up to RT and magnetically stirred until a large amount of white solid (crystallized PEO) appeared (in $c a .3 \mathrm{~h}$ ). The product was dissolved in dichloromethane (DCM), followed by precipitation in cold diethyl ether and vacuum drying overnight at $40{ }^{\circ} \mathrm{C}$. The agreement between $M_{\mathrm{n}, \mathrm{SEC}}$ and theoretical number-average molar mass $\left(M_{\mathrm{n}, \mathrm{th}}\right)$ calculated from feed ratio of EO and SA confirms complete consumption of EO. $M_{\mathrm{n} \text {,th }}=3.5 \mathrm{~kg} \mathrm{~mol}^{-1}$. $M_{\mathrm{n}, \mathrm{SEC}}(\mathrm{DMF}, \mathrm{PEO}$ standards $)=3.9 \mathrm{~kg} \mathrm{~mol}^{-1}, \bigoplus_{\mathrm{M}}=1.12 .{ }^{1} \mathrm{H} \mathrm{NMR}\left(400 \mathrm{MHz}, \mathrm{CDCl}_{3}\right): \delta / \mathrm{ppm}$ $=4.26-4.20\left(-\mathrm{COOCH}_{2} \mathrm{CH}_{2} \mathrm{O}^{-}\right), 3.82-3.45\left(-\mathrm{OCH}_{2} \mathrm{CH}_{2} \mathrm{O}^{-}\right)$, 3.74-3.71 $\left(-\mathrm{OCH}_{2} \mathrm{CH}_{2} \mathrm{OH}\right)$, $2.35-2.30 \quad\left(-\mathrm{CH}_{2} \mathrm{CH}_{2} \mathrm{COO}-\right), \quad 1.67-1.58 \quad\left(-\mathrm{CH}_{2} \mathrm{CH}_{2} \mathrm{COO}^{-}\right), \quad 1.36-1.13$ $\left(\mathrm{CH}_{3}\left(\mathrm{CH}_{2}\right)_{14} \mathrm{CH}_{2} \mathrm{CH}_{2} \mathrm{COO}^{-}\right), 0.93-0.83\left(\mathrm{CH}_{3}\left(\mathrm{CH}_{2}\right){ }_{14} \mathrm{CH}_{2} \mathrm{CH}_{2} \mathrm{COO}^{-}\right) . M_{\mathrm{n}, \mathrm{NMR}}=3.6 \mathrm{~kg} \mathrm{~mol}^{-1}$. Block Copolymerization of PO and EO, and Alkaline Hydrolysis of the $\alpha$-end. Synthetic procedure for PPO precursor was similar to SA-PO, using SA (0.38 g, $1.33 \mathrm{mmol}), t$-BuP2 (2.0 M, $33 \mu \mathrm{L}, 0.066 \mathrm{mmol}), \mathrm{Et}_{3} \mathrm{~B}$ solution $(1.0 \mathrm{M}, 0.20 \mathrm{~mL}, 0.2 \mathrm{mmol})$, and PO $(3.3 \mathrm{~mL}$, $47.0 \mathrm{mmol}$ ). After the mixture was stirred at RT for $12 \mathrm{~h}$, a small aliquot was withdrawn in a glovebox, diluted with THF for SEC measurement. $M_{\mathrm{n}, \mathrm{th}}=2.3 \mathrm{~kg} \mathrm{~mol}^{-1} \cdot M_{\mathrm{n}, \mathrm{SEC}}$ (THF, PS standards $)=3.5 \mathrm{~kg} \mathrm{~mol}^{-1}, \bigoplus_{\mathrm{M}}=1.06$. Then $\mathrm{EO}(3.0 \mathrm{~mL}, 60 \mathrm{mmol})$ was added to the mixture of PPO and catalysts. The new reaction mixture was stirred at RT for another $2 \mathrm{~h}$ until a large amount of white solid appeared. After dissolution with DCM, the crude product was poured into cold $n$-hexane. The copolymer was collected by centrifugation and dried in vacuum at $40{ }^{\circ} \mathrm{C}$ overnight. $M_{\mathrm{n}, \mathrm{th}}=4.3 \mathrm{~kg} \mathrm{~mol}^{-1} \cdot M_{\mathrm{n}, \mathrm{SEC}}(\mathrm{DMF}, \mathrm{PEO}$ standards $)=3.3 \mathrm{~kg} \mathrm{~mol}^{-1}, \bigoplus_{\mathrm{M}}=1.22$. 
${ }^{1} \mathrm{H}$ NMR $\left(400 \mathrm{MHz}, \mathrm{CDCl}_{3}\right): \delta / \mathrm{ppm}=4.08-4.00\left(-\mathrm{COOCH}_{2} \mathrm{CH}\left(\mathrm{CH}_{3}\right) \mathrm{O}-\right), \quad 3.78-3.60$ $\left(-\mathrm{OCH}_{2} \mathrm{CH}_{2} \mathrm{O}-\right), 3.74-3.71 \quad\left(-\mathrm{OCH}_{2} \mathrm{CH}_{2} \mathrm{OH}\right), \quad 3.58-3.46\left(-\mathrm{OCH}_{2} \mathrm{CH}\left(\mathrm{CH}_{3}\right) \mathrm{O}^{-}\right), \quad 3.46-3.34$ $\left(-\mathrm{OCH}_{2} \mathrm{CH}\left(\mathrm{CH}_{3}\right) \mathrm{O}^{-}\right), 2.35-2.30\left(-\mathrm{CH}_{2} \mathrm{CH}_{2} \mathrm{COO}-\right), 1.65-1.58\left(-\mathrm{CH}_{2} \mathrm{CH}_{2} \mathrm{COO}-\right), 1.34-1.20$ $\left(\mathrm{CH}_{3}\left(\mathrm{CH}_{2}\right)_{14} \mathrm{CH}_{2} \mathrm{CH}_{2} \mathrm{COO}^{-}\right), \quad 1.18-1.10 \quad\left(-\mathrm{OCH}_{2} \mathrm{CH}\left(\mathrm{CH}_{3}\right) \mathrm{O}^{-}\right), \quad 0.90-0.85$ $\left(\mathrm{CH}_{3}\left(\mathrm{CH}_{2}\right)_{14} \mathrm{CH}_{2} \mathrm{CH}_{2} \mathrm{COO}-\right) \cdot M_{\mathrm{n}, \mathrm{NMR}}=2.0(\mathrm{PPO})+2.4(\mathrm{PEO}) \mathrm{kg} \mathrm{mol}^{-1}$.

The $\alpha$-(stearic ester)- $\omega$-hydroxy PPO- $b$-PEO $(0.44 \mathrm{~g}, 0.10 \mathrm{mmol})$ was loaded in a flask and dissolved in THF $(5.0 \mathrm{~mL})$. KOH $(50.0 \mathrm{mg}, 0.90 \mathrm{mmol})$ was dissolved in $0.10 \mathrm{~mL}$ of water and added to the copolyether. The mixture was stirred at $40{ }^{\circ} \mathrm{C}$ for $4 \mathrm{~h}$ before a small aliquot was withdrawn for ${ }^{1} \mathrm{H}$ NMR analysis to confirm complete hydrolysis of the $\alpha$-end ester group. After addition of a few drops of $\mathrm{HCl}$ solution $(5.0 \mathrm{M})$ for acidification, the product was precipitated in cold $n$-hexane, followed by centrifugation and vacuum drying. $M_{\mathrm{n}, \mathrm{SEC}}(\mathrm{DMF}$, PEO standards $)=3.7 \mathrm{~kg} \mathrm{~mol}^{-1}, \bigoplus_{\mathrm{M}}=1.22 .{ }^{1} \mathrm{H} \mathrm{NMR}\left(400 \mathrm{MHz}, \mathrm{CDCl}_{3}\right): \delta / \mathrm{ppm}=3.80-3.60$ $\left(-\mathrm{OCH}_{2} \mathrm{CH}_{2} \mathrm{O}^{-}\right), 3.74-3.71 \quad\left(-\mathrm{OCH}_{2} \mathrm{CH}_{2} \mathrm{OH}\right), \quad 3.60-3.48\left(-\mathrm{OCH}_{2} \mathrm{CH}\left(\mathrm{CH}_{3}\right) \mathrm{O}^{-}\right), \quad 3.48-3.34$ $\left(-\mathrm{OCH}_{2} \mathrm{CH}\left(\mathrm{CH}_{3}\right) \mathrm{O}^{-}\right), 1.27-1.01\left(-\mathrm{OCH}_{2} \mathrm{CH}\left(\mathrm{CH}_{3}\right) \mathrm{O}^{-}\right) \cdot M_{\mathrm{n}, \mathrm{NMR}}=1.8(\mathrm{PPO})+2.4(\mathrm{PEO}) \mathrm{kg}$ $\mathrm{mol}^{-1}$.

Diacid-Initiated ROP of PO and One-Pot Synthesis of Ester-Functionalized Polyurethane. Synthetic procedure for the $\alpha, \omega$-dihydroxyl PPO with two central ester groups was similar to that of SA-PO, using GA $(0.13 \mathrm{~g}, 1.0 \mathrm{mmol})$, THF $(2.50 \mathrm{~mL}), t-\mathrm{BuP}_{2}$ solution $(2.0 \mathrm{M}, 50 \mu \mathrm{L}$, $0.10 \mathrm{mmol})$, Et 3 B solution $(1.0 \mathrm{M}, 300 \mu \mathrm{L}, 0.30 \mathrm{mmol})$, and PO (2.81 mL, $40.0 \mathrm{mmol})$. After the mixture was stirred at RT for $6 \mathrm{~h}$, a small aliquot was withdrawn in a glovebox for ${ }^{1} \mathrm{H}$ NMR, SEC, and MALDI-TOF MS measurements. Conv.(PO) $=100 \%, M_{\mathrm{n}, \mathrm{th}}=2.6 \mathrm{~kg} \mathrm{~mol}^{-1}$. $M_{\mathrm{n}, \mathrm{SEC}}(\mathrm{THF}, \mathrm{PS}$ standards $)=4.0 \mathrm{~kg} \mathrm{~mol}^{-1}, \bigoplus_{\mathrm{M}}=1.06 .{ }^{1} \mathrm{H} \mathrm{NMR}\left(400 \mathrm{MHz}, \mathrm{CDCl}_{3}\right): \delta / \mathrm{ppm}=$ 4.09-4.01 (- $\left.\mathrm{COOCH}_{2} \mathrm{CH}\left(\mathrm{CH}_{3}\right) \mathrm{O}^{-}\right), \quad 3.96-3.88 \quad\left(-\mathrm{OCH}_{2} \mathrm{CH}\left(\mathrm{CH}_{3}\right) \mathrm{OH}\right), \quad 3.70-3.47$ $\left(-\mathrm{OCH}_{2} \mathrm{CH}\left(\mathrm{CH}_{3}\right) \mathrm{O}^{-}\right), \quad 3.47-3.28 \quad\left(-\mathrm{OCH}_{2} \mathrm{CH}\left(\mathrm{CH}_{3}\right) \mathrm{O}^{-}\right), \quad 2.44-2.37$ 
$\left(-\mathrm{OOCCH}_{2} \mathrm{CH}_{2} \mathrm{CH}_{2} \mathrm{COO}-\right), \quad 1.99-1.91 \quad\left(-\mathrm{OOCCH}_{2} \mathrm{CH}_{2} \mathrm{CH}_{2} \mathrm{COO}^{-}\right), \quad 1.26-1.03$ $\left(-\mathrm{OCH}_{2} \mathrm{CH}\left(\mathrm{CH}_{3}\right) \mathrm{O}^{-}\right) . M_{\mathrm{n}, \mathrm{NMR}}=2.7 \mathrm{~kg} \mathrm{~mol}^{-1}$.

Then HDI $(0.16 \mathrm{~mL}, 1.0 \mathrm{mmol})$ was added to the mixture of PPO and catalysts. The new reaction mixture was stirred for another $2 \mathrm{~h}$, during which a distinct viscosity increase was observed until the stirrer stopped spinning. The product was diluted with THF, poured into water to precipitate, and dried in a vacuum oven at $60^{\circ} \mathrm{C} . M_{\mathrm{n}, \mathrm{SEC}}(\mathrm{THF}, \mathrm{PS}$ standards $)=20.3$ $\mathrm{kg} \quad \mathrm{mol}^{-1}, \quad \bigoplus_{\mathrm{M}}=2.0 . \quad{ }^{1} \mathrm{H} \quad \mathrm{NMR} \quad\left(400 \quad \mathrm{MHz}, \quad \mathrm{CDCl}_{3}\right): \quad \delta / \mathrm{ppm}=4.94-4.70$ $\left(-\mathrm{OCH}_{2} \mathrm{CH}\left(\mathrm{CH}_{3}\right) \mathrm{OCONH}-\right), \quad 4.09-4.00 \quad\left(-\mathrm{COOCH}_{2} \mathrm{CH}\left(\mathrm{CH}_{3}\right) \mathrm{O}^{-}\right), \quad 3.70-3.45$ $\left(-\mathrm{OCH}_{2} \mathrm{CH}\left(\mathrm{CH}_{3}\right) \mathrm{O}^{-}\right), 3.45-3.30\left({ }^{-} \mathrm{OCH}_{2} \mathrm{CH}\left(\mathrm{CH}_{3}\right) \mathrm{O}^{-}\right), 3.20-3.05\left(-\mathrm{CH}_{2} \mathrm{NHCOO}^{-}\right), 2.43-$ 2.38 (- $\left.\mathrm{OOCCH}_{2} \mathrm{CH}_{2} \mathrm{CH}_{2} \mathrm{COO}-\right), \quad 1.99-1.92 \quad\left(-\mathrm{OOCCH}_{2} \mathrm{CH}_{2} \mathrm{CH}_{2} \mathrm{COO}-\right), \quad 1.57-1.41$ $\left(-\mathrm{CH}_{2} \mathrm{CH}_{2} \mathrm{NHCOO}^{-}\right), \quad 1.36-1.29 \quad\left(-\mathrm{CH}_{2} \mathrm{CH}_{2} \mathrm{CH}_{2} \mathrm{NHCOO}^{-}\right), \quad 1.26-1.19$ $\left(-\mathrm{OCH}_{2} \mathrm{CH}\left(\mathrm{CH}_{3}\right) \mathrm{OCONH}^{-}\right), 1.19-0.97\left(-\mathrm{OCH}_{2} \mathrm{CH}\left(\mathrm{CH}_{3}\right) \mathrm{O}^{-}\right)$. 


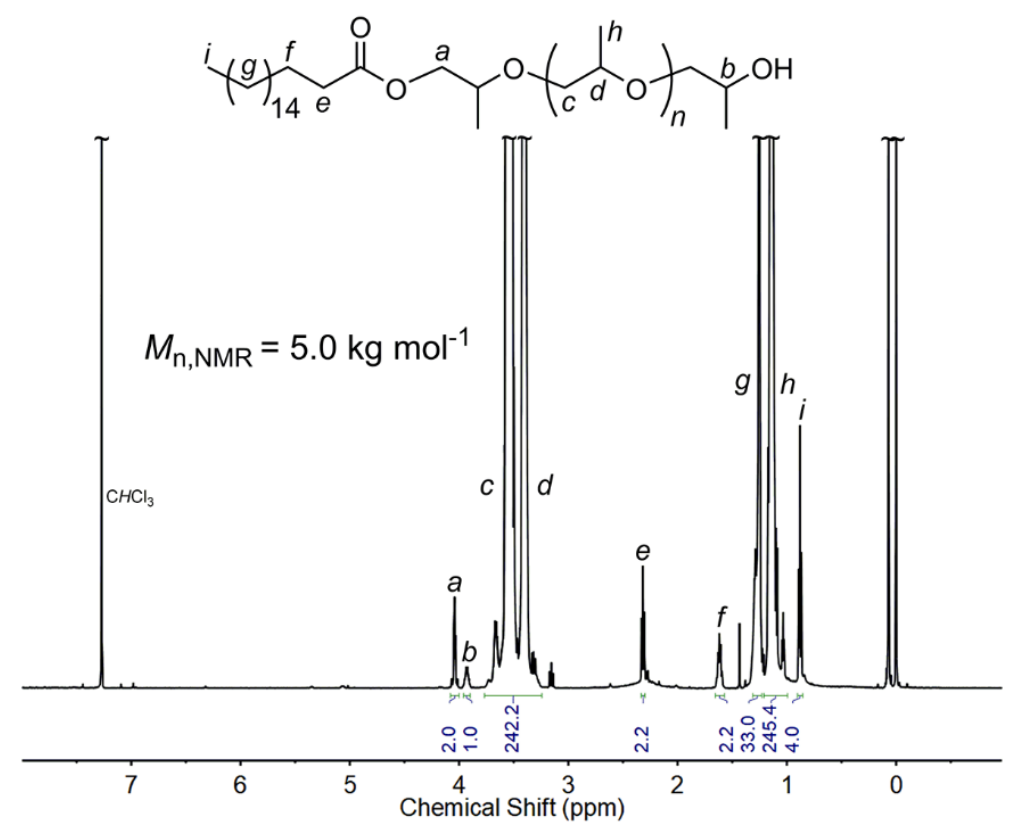

Figure S1. ${ }^{1} \mathrm{H}$ NMR spectrum of the product of SA-PO (Table 1) with integrals noted.

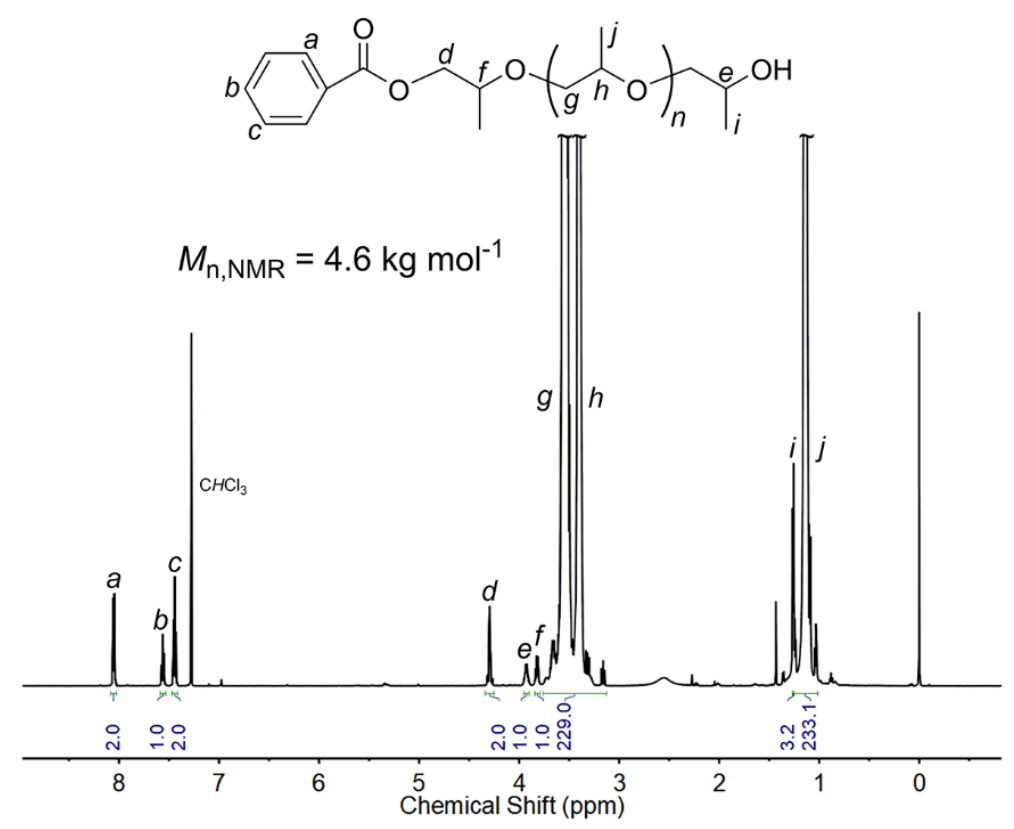

Figure S2. ${ }^{1} \mathrm{H}$ NMR spectrum of the product of BA-PO (Table 1) with integrals noted. 


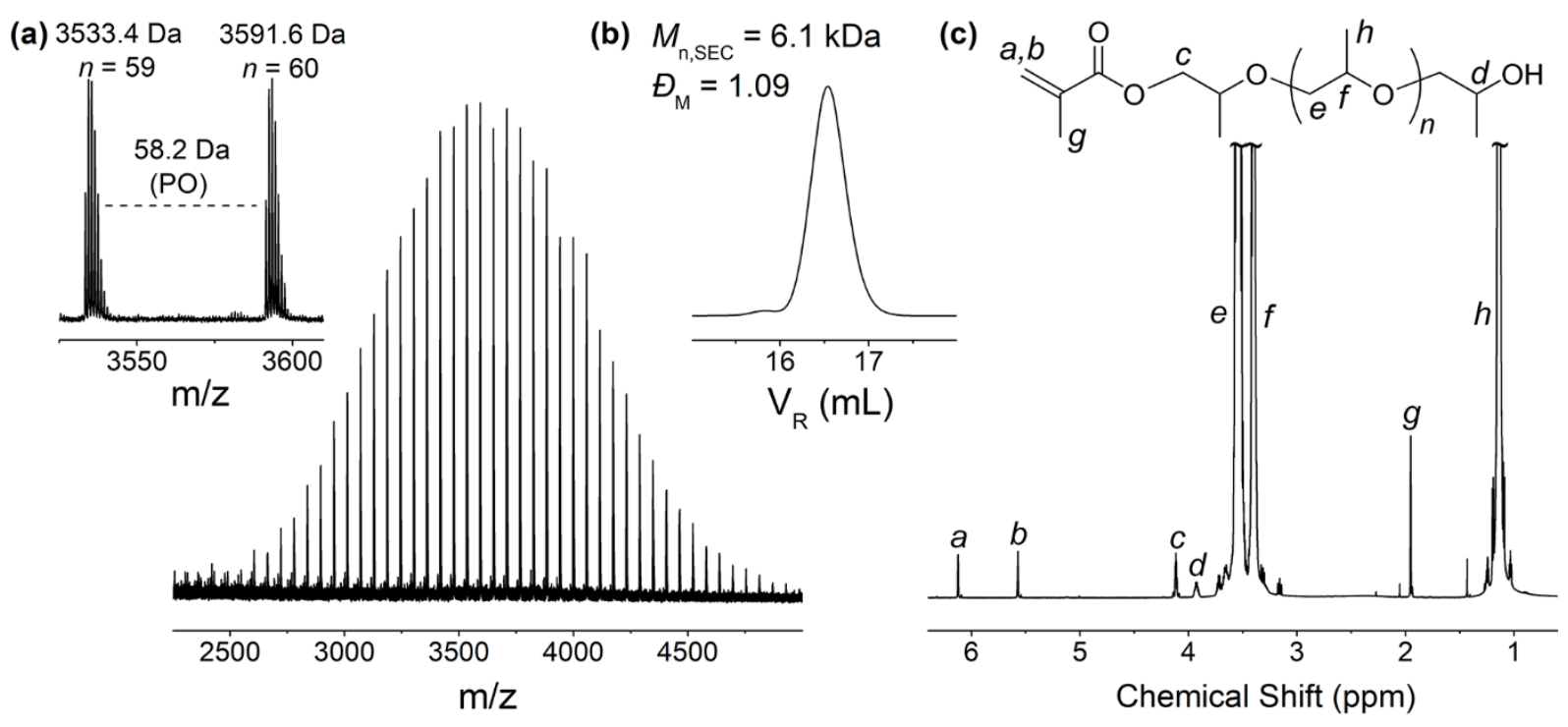

Figure S3. MALDI-TOF MS spectrum (a), SEC trace (b), and ${ }^{1} \mathrm{H}$ NMR spectrum (c) of the $\alpha$-(methacrylic ester)- $\omega$-hydroxy PPO synthesized with MA as the initiator and $t-\mathrm{BuP}_{2}+\mathrm{Et}_{3} \mathrm{~B}$ as the catalyst (MA-PO in Table 1).

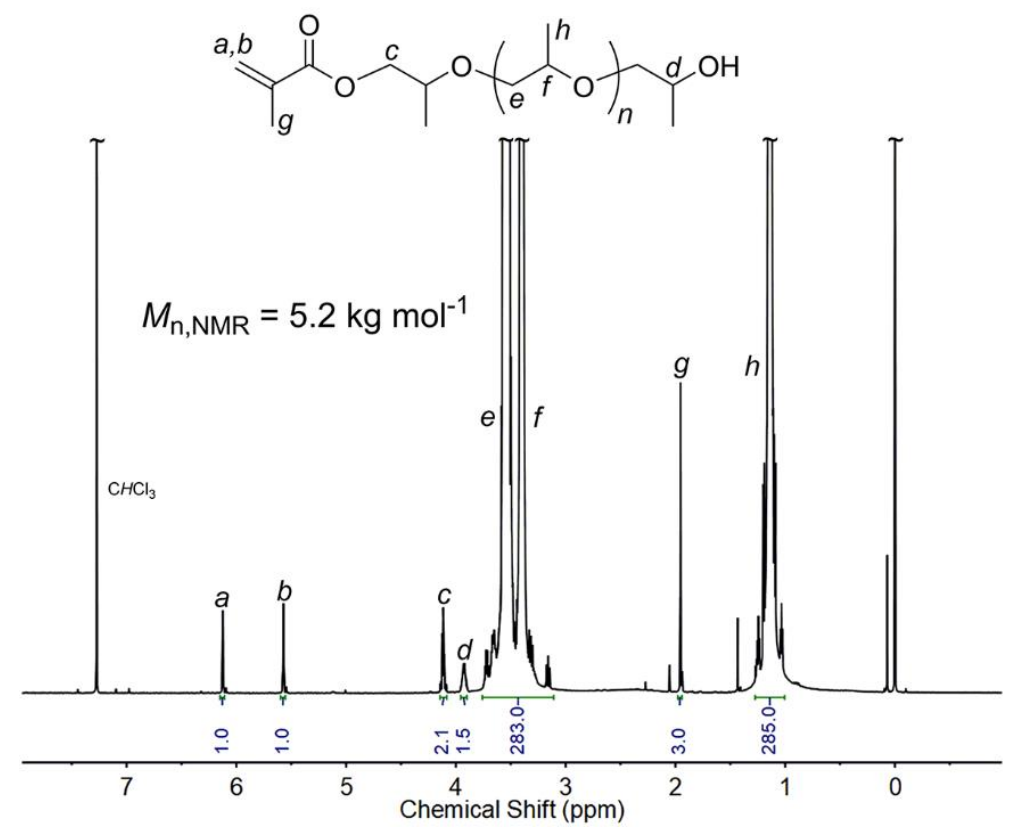

Figure S4. ${ }^{1}$ H NMR spectrum of the product of MA-PO (Table 1) with integrals noted. 


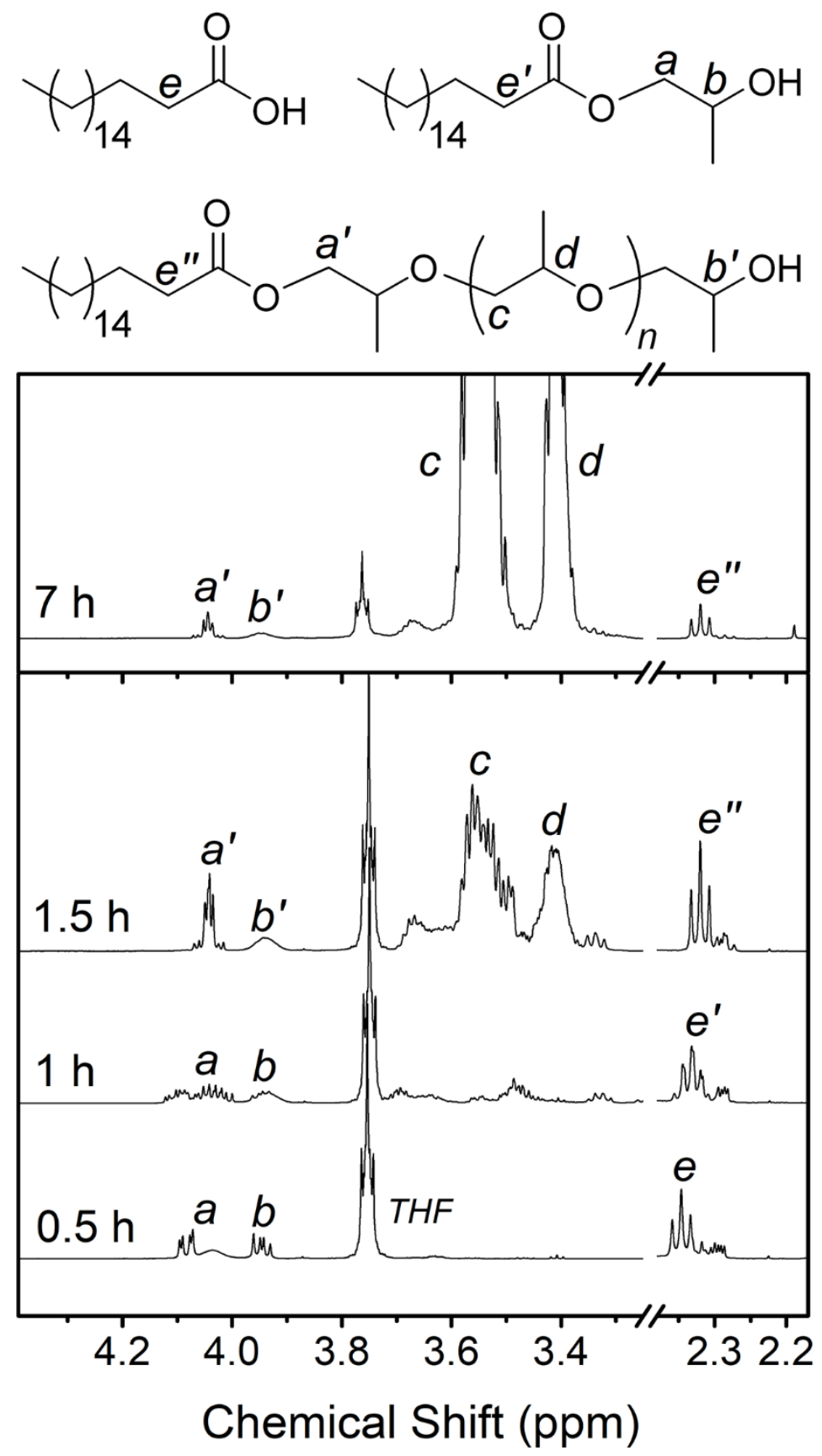

Figure S5. ${ }^{1} \mathrm{H}$ NMR spectra of aliquots withdrawn at different reaction times from SA-PO (Table 1). 

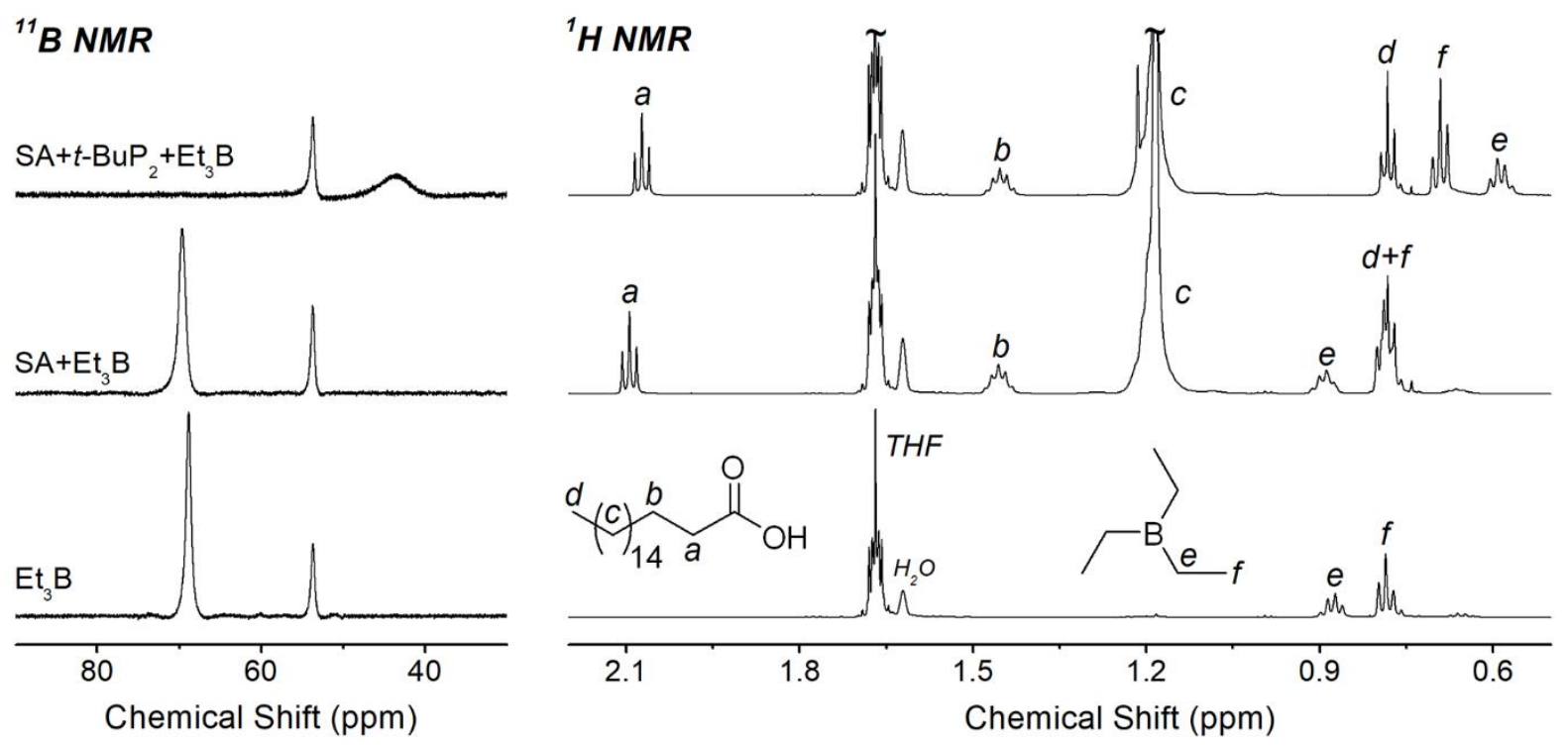

Figure S6. ${ }^{11} \mathrm{~B}$ NMR (left) and ${ }^{1} \mathrm{H}$ NMR (right) spectra of Et $3 \mathrm{~B}$ mixed with SA and SA+t$\mathrm{BuP}_{2}$ in a molar ratio of $1 / 0.3$ and $1 / 0.1 / 0.3$, respectively. For each measurement, $8 \mu \mathrm{L}$ of $\mathrm{Et}_{3} \mathrm{~B}$ solution (1.0 M in THF) is added in $0.60 \mathrm{~mL}$ of THF- $d_{8}$. 
Initiation (esterification of $\mathrm{COOH}$ )

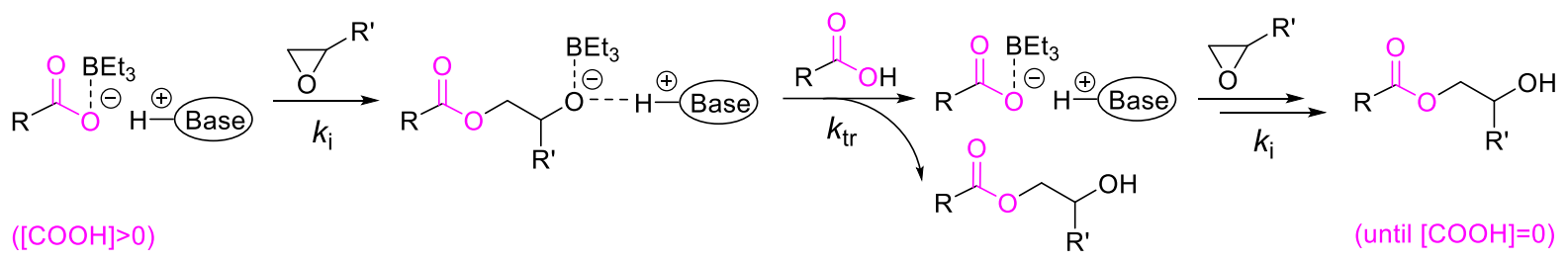

Propagation (transesterification-free)

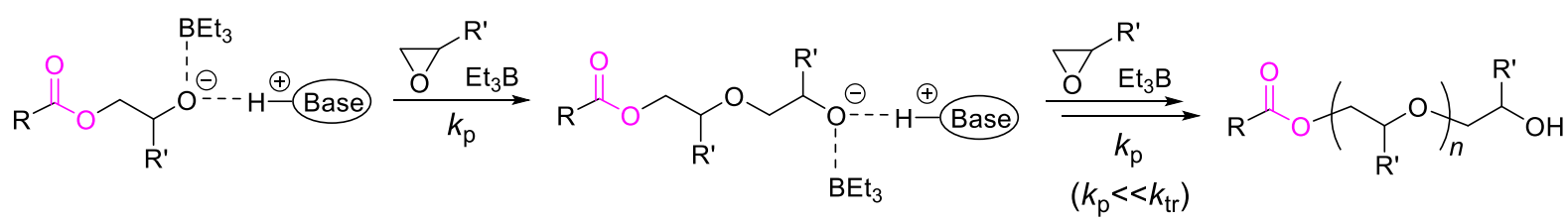

Scheme S1. The two-stage mechanistic pathway of carboxylic acid-initiated ROP of epoxides by the catalysis of PB (base) and $\mathrm{Et}_{3} \mathrm{~B}$. 
(a) 4856.4 Da 4928.6 Da

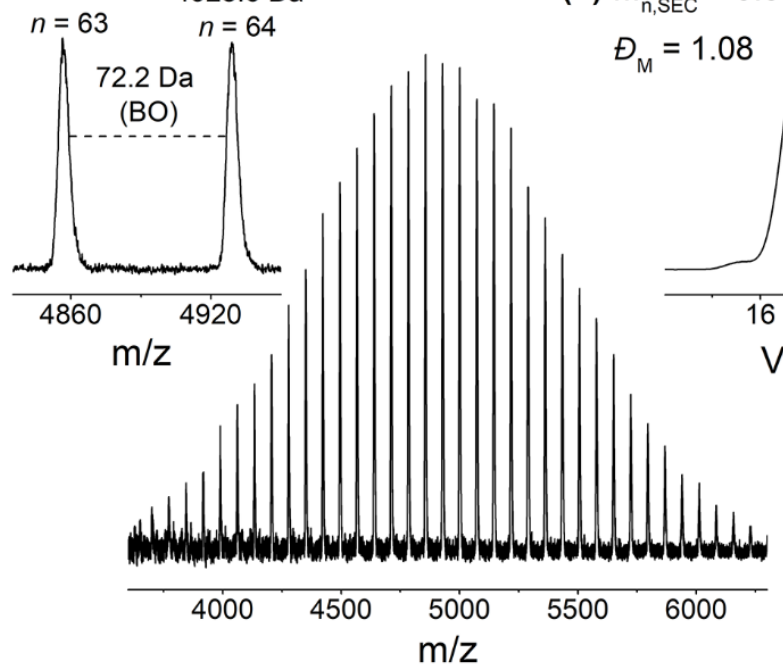

(b) $M_{\mathrm{n}, \mathrm{SEC}}=5.8 \mathrm{kDa}$

$=1.08$

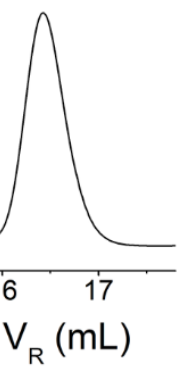

(c)<smiles>CCCCC(=O)OCC(CC)OC1(C)CCC(OC(C)(C)O)C1C</smiles>

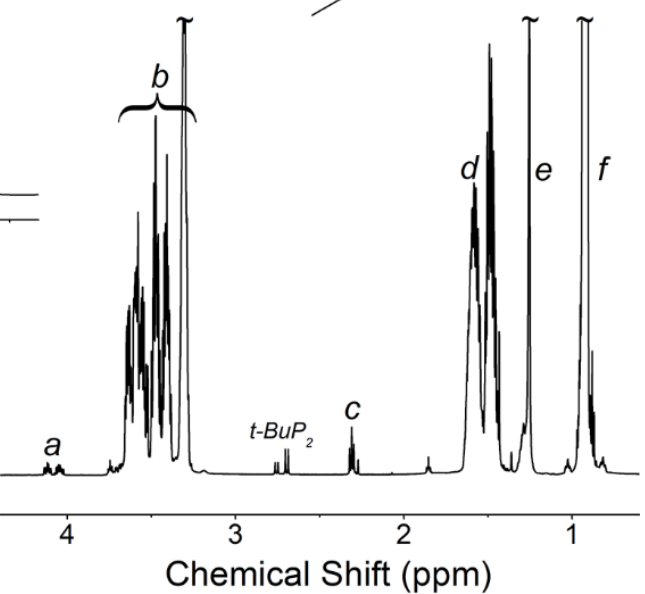

Figure S7. MALDI-TOF MS spectrum (a), SEC trace (b), and ${ }^{1} \mathrm{H}$ NMR spectrum (c) of the $\alpha$-(stearic ester)- $\omega$-hydroxy PBO synthesized with SA as the initiator and $t$ - $\mathrm{BuP}_{2}+\mathrm{Et}_{3} \mathrm{~B}$ as the catalyst (SA-BO in Table 1).

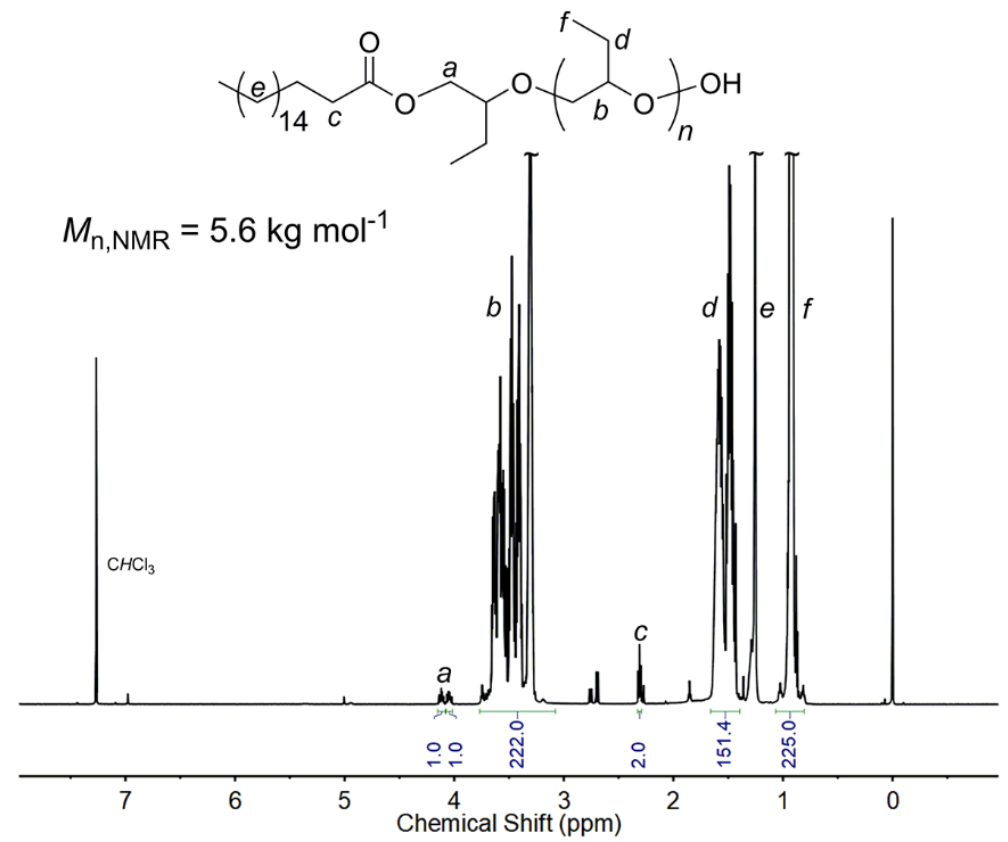

Figure S8. ${ }^{1} \mathrm{H}$ NMR spectrum of the product of SA-BO (Table 1) with integrals noted. 


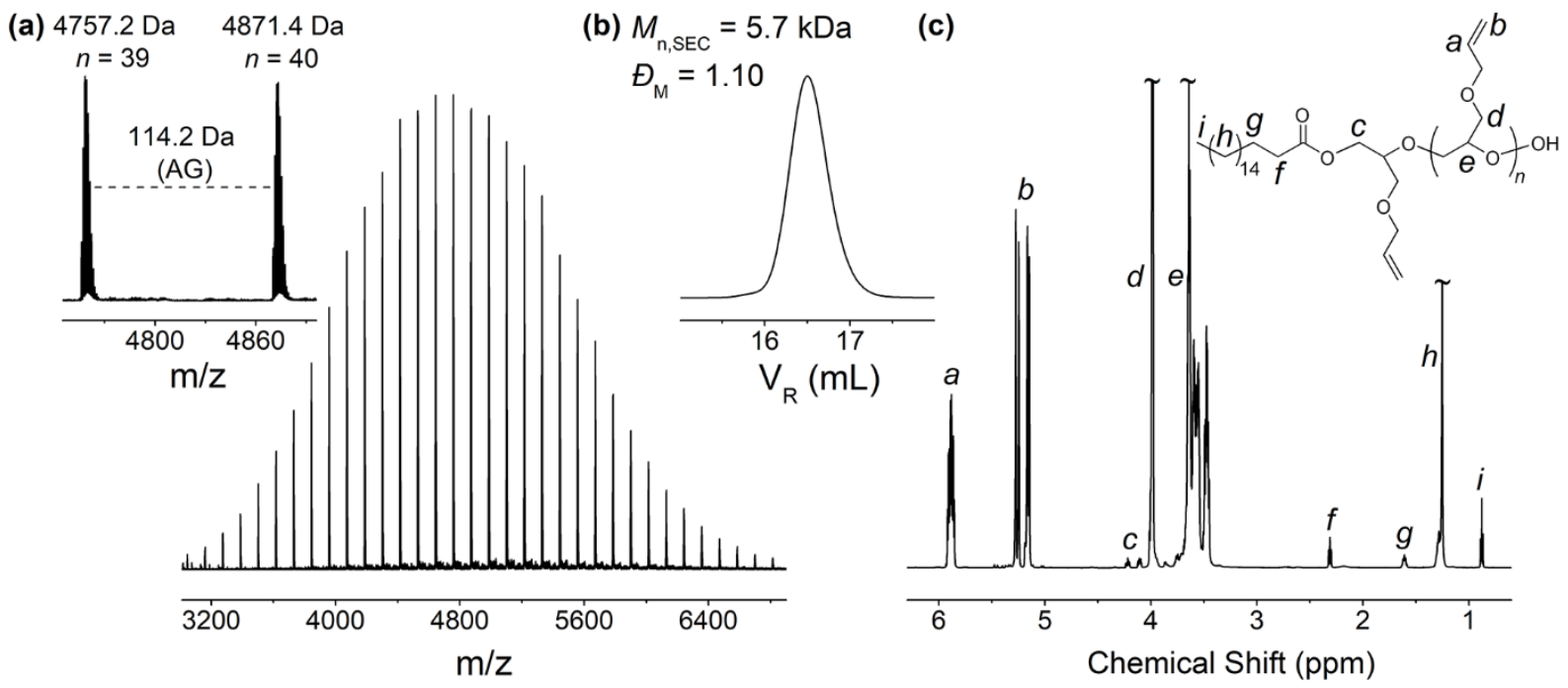

Figure S9. MALDI-TOF MS spectrum (a), SEC trace (b), and ${ }^{1} \mathrm{H}$ NMR spectrum (c) of the $\alpha$-(stearic ester)- $\omega$-hydroxy PAG synthesized with SA as the initiator and $t$ - $\mathrm{BuP}_{2}+\mathrm{Et}_{3} \mathrm{~B}$ as the catalyst (SA-AG in Table 1).

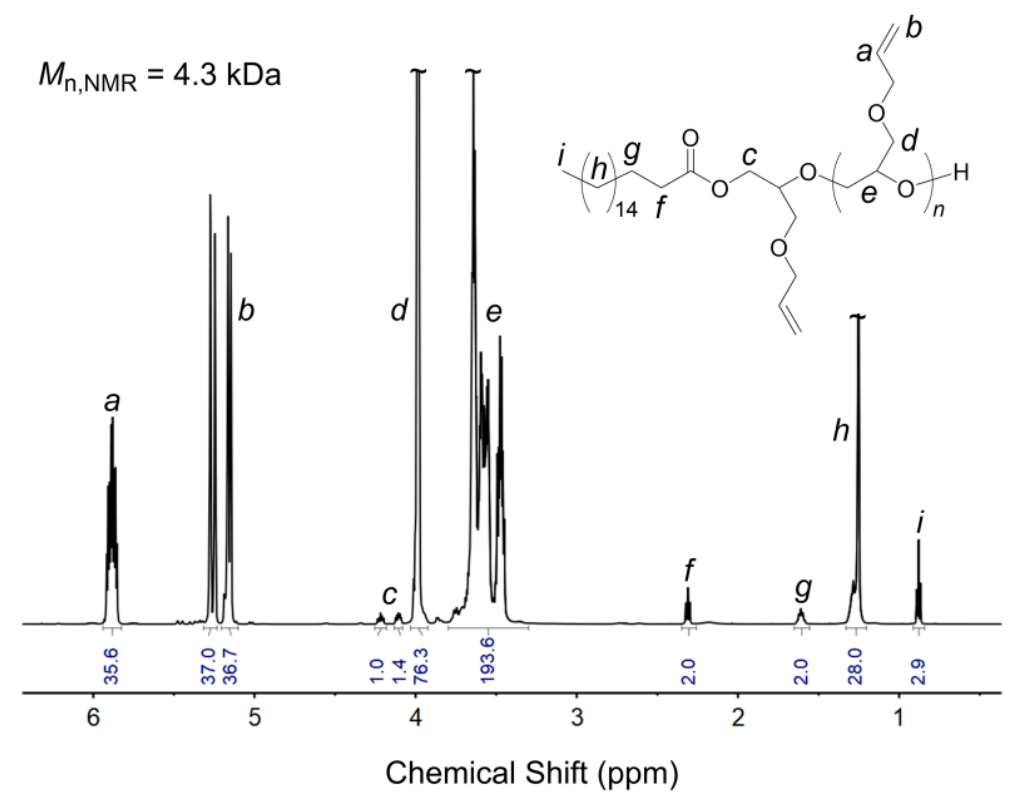

Figure S10. ${ }^{1} \mathrm{H}$ NMR spectrum of the product of SA-AG (Table 1) with integrals noted. 

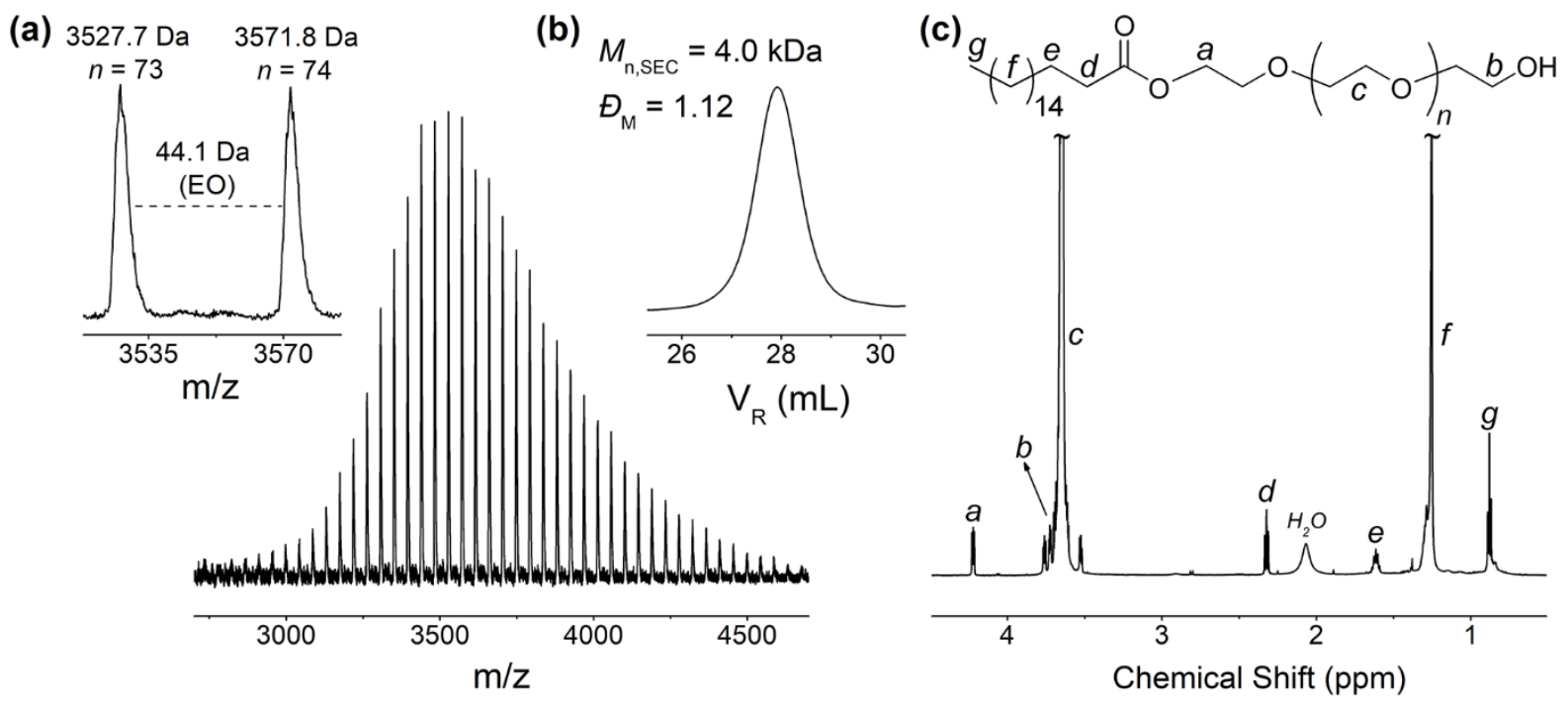

Figure S11. MALDI-TOF MS spectrum (a), SEC trace (b), and ${ }^{1} \mathrm{H}$ NMR spectrum (c) of the $\alpha$-(stearic ester)- $\omega$-hydroxy PEO synthesized with SA as the initiator and $t$ - $\mathrm{BuP}_{1}+\mathrm{Et}_{3} \mathrm{~B}$ as the catalyst (SA-EO in Table 1).

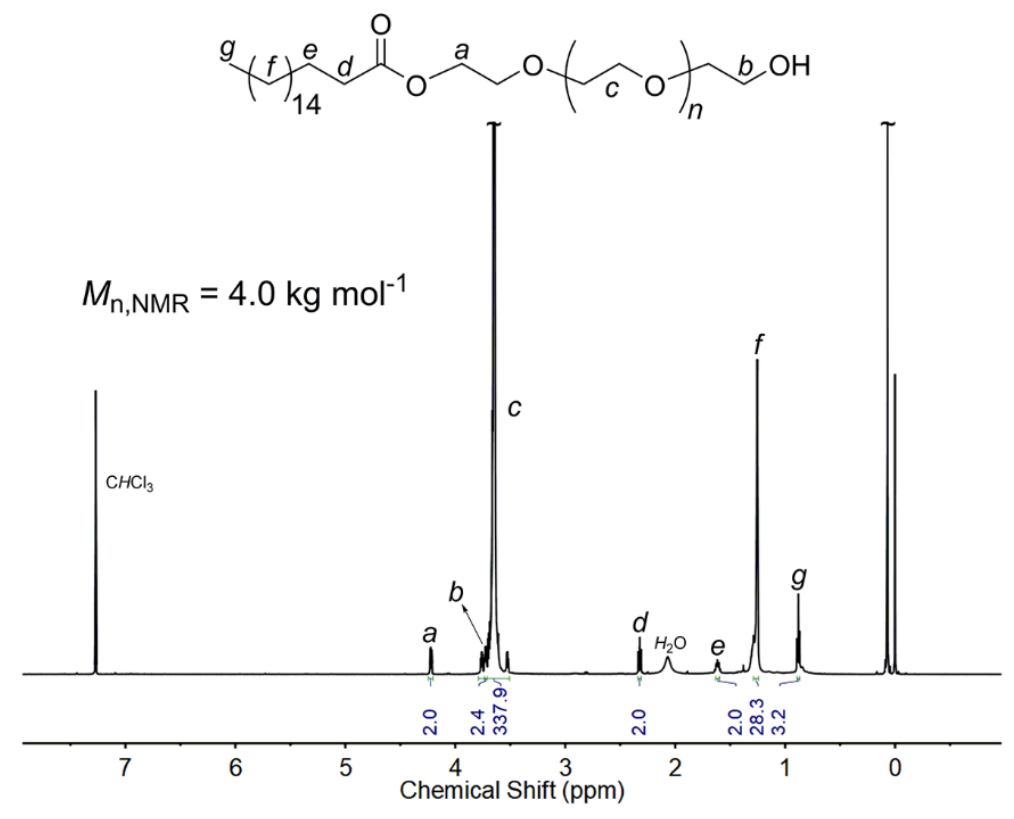

Figure S12. ${ }^{1} \mathrm{H}$ NMR spectrum of the product of SA-EO (Table 1) with integrals noted. 
(a)

$M_{\mathrm{n}, \mathrm{SEC}}=3.3 \mathrm{~kg} \mathrm{~mol}^{-1}$

$\Theta_{\mathrm{M}}=1.22$

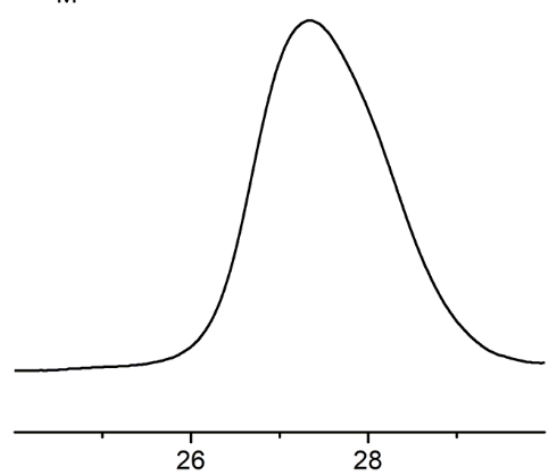

Retention Volume (mL)

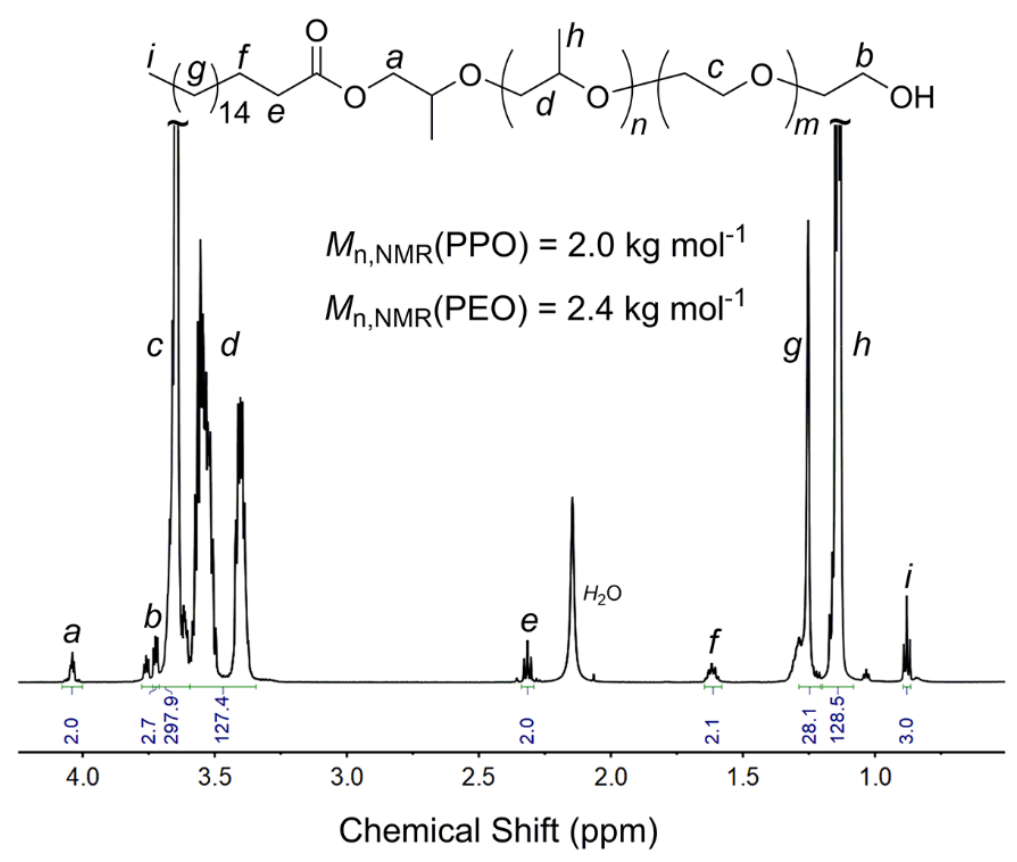

(b)

$M_{\mathrm{n}, \mathrm{SEC}}=3.7 \mathrm{~kg} \mathrm{~mol}^{-1}$

$\bigoplus_{\mathrm{M}}=1.22$

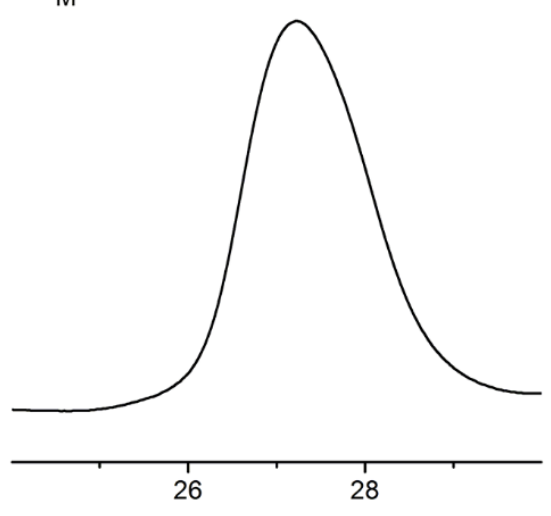

Retention Volume ( $\mathrm{mL}$ )

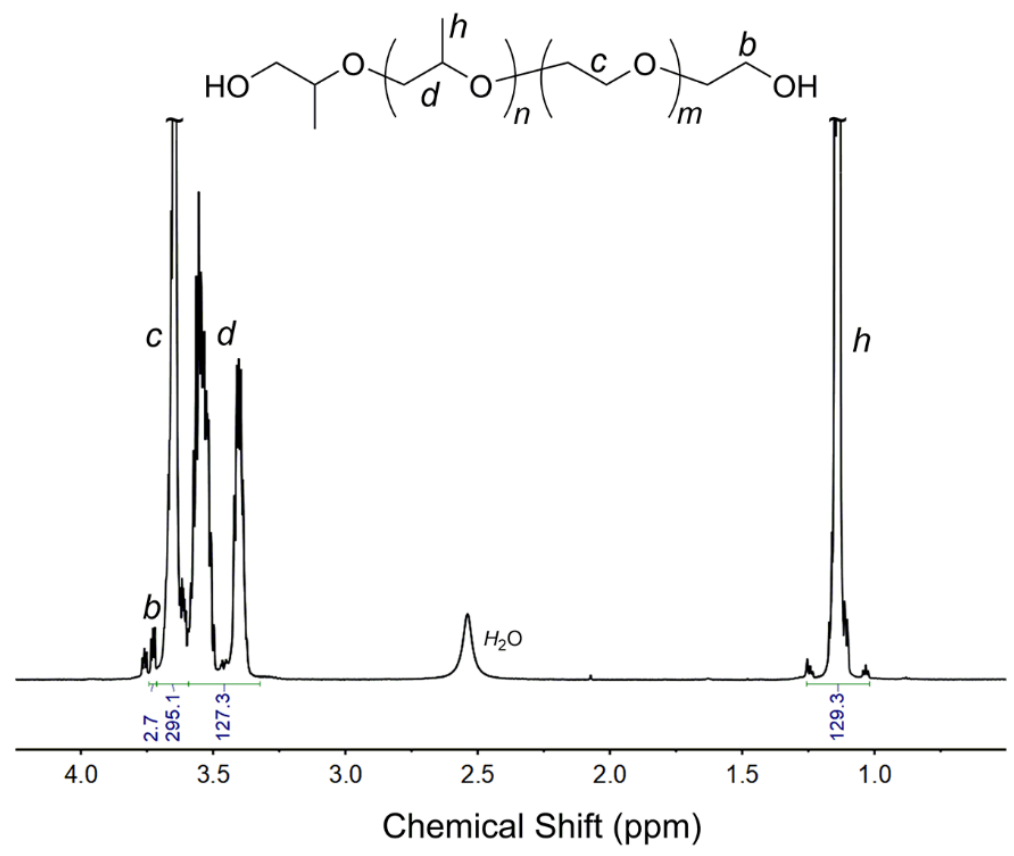

Figure S13. SEC trace (left) and ${ }^{1} \mathrm{H}$ NMR spectrum (right) of the $\alpha$-(stearic ester)- $\omega$-hydroxy PPO- $b$-PEO block copolymer (a) and the $\alpha, \omega$-di(primary)hydroxy PPO- $b$-PEO (b) obtained after hydrolysis of the $\alpha$-end ester group (Scheme 1b). 

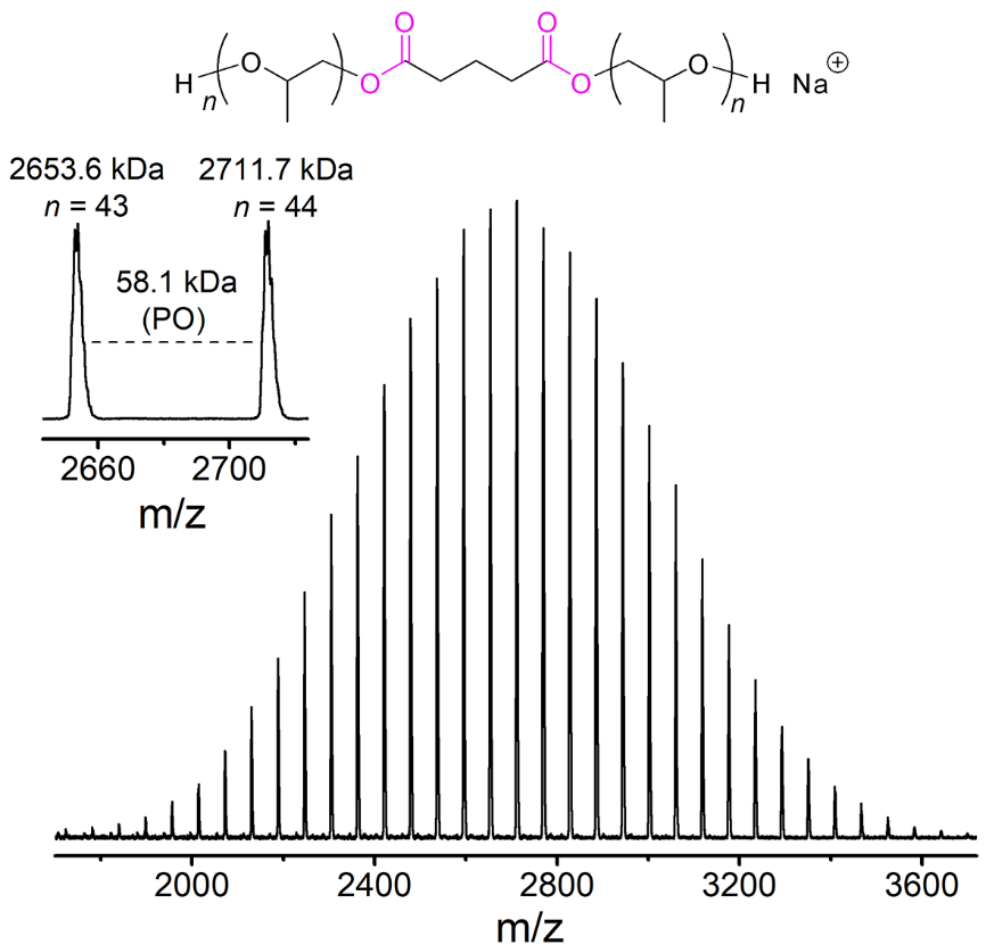

Figure S14. MALDI-TOF MS spectrum of the $\alpha, \omega$-dihydroxy PPO synthesized with GA as the initiator and $t-\mathrm{BuP}_{2}+\mathrm{Et}_{3} \mathrm{~B}$ as the catalyst (GA-PO in Table 1). 
(a)

$M_{\mathrm{n}, \mathrm{SEC}}=4.0 \mathrm{~kg} \mathrm{~mol}^{-1}$

$\oplus_{\mathrm{M}}=1.05$
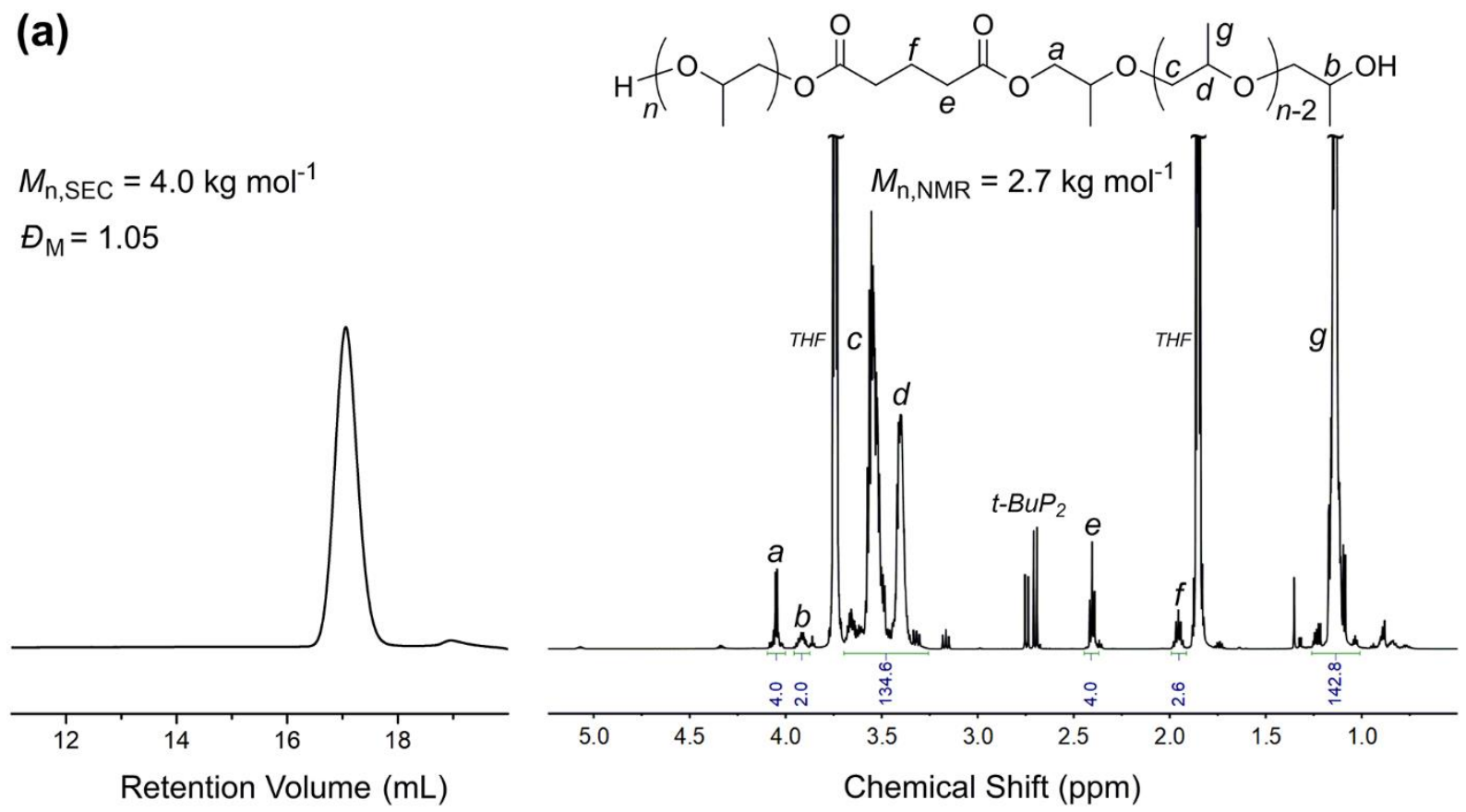

(b)

$M_{\mathrm{n}, \mathrm{SEC}}=20.1 \mathrm{~kg} \mathrm{~mol}^{-1}$

$\theta_{\mathrm{M}}=1.99$
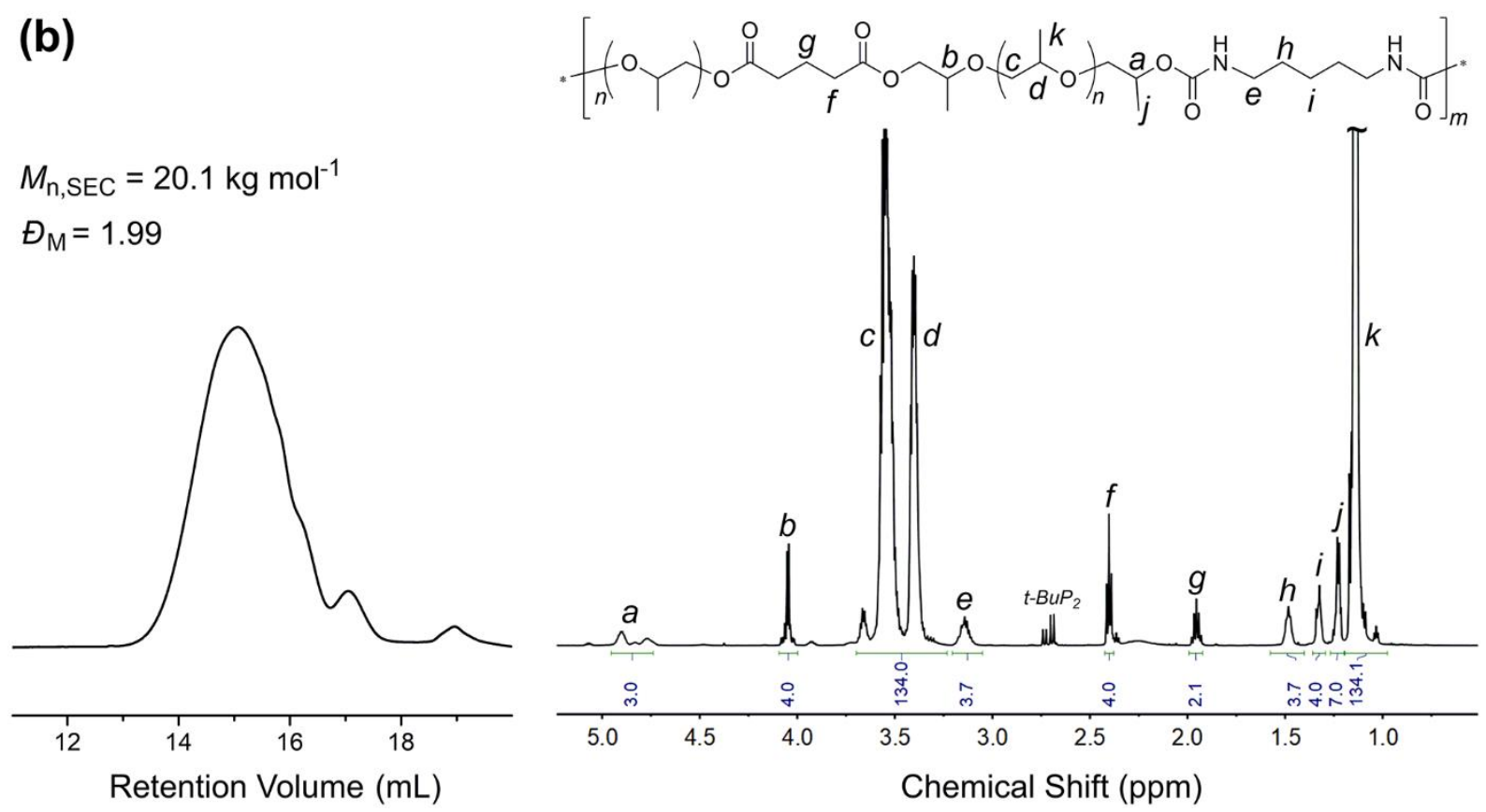

Figure S15. SEC trace (left) and ${ }^{1} \mathrm{H}$ NMR spectrum (right) of the PPO-diol initiated by GA (a) (GA-PO in Table 1) and the subsequently formed ester-embedded PPO-PU (b) (Scheme 1c). 


\section{Reference}

(1) (a) Janshoff, A.; Galla, H. J.; Steinem, C., Piezoelectric Mass-Sensing Devices as Biosensors-an Alternative to Optical Biosensors? Angew. Chem. Int. Ed. 2000, 39, 4004-4032;

(b) Voinova, M. V.; Rodahl, M.; Jonson, M.; Kasemo, B., Viscoelastic Acoustic Response of Layered Polymer Films at Fluid-Solid Interfaces: Continuum Mechanics Approach. Phys. Scr. 1999, 59, 391-396; (c) Rodahl, M.; Höök, F.; Krozer, A.; Brzezinski, P.; Kasemo, B., Quartz Crystal Microbalance Setup for Frequency and Q-Factor Measurements in Gaseous and Liquid Environments. Rev. Sci. Instrum. 1995, 66, 3924-3930. 